\title{
Iris Menn \\ Beach morphology and food web structure: comparison of an eroding and an accreting sandy shore in the North Sea
}

Received: 15 August 2001 / Revised: 2 April 2002 / Accepted: 4 April 2002 / Published online: 22 May 2002

(C) Springer-Verlag and AWI 2002

\begin{abstract}
Food web components and inorganic nutrients were studied on two sandy shores of the adjacent barrier islands of Sylt and Rømø in the North Sea, differing in morphodynamics. Implications of high and low wave energy on the food web structure were assessed. The Sylt shore represents a dynamic intermediate beach type, while the Rømø shore is morphologically stable and dissipative. On the steep-profiled, coarse-grained Sylt shore, strong hydrodynamics resulted in erosion and high fluxes of organic material through the beach, but prevented any storage of food sources. In contrast, the flatprofiled, fine-grained Røm $\varnothing$ shore, with low wave energy and accretion, accumulated organic carbon from surf waters. At Sylt, oxic nutrient regeneration prevailed, while anoxic mineralization was more important at Rømø. Macrofauna on the Sylt shore was impoverished compared with the community at Rømø. Correspondingly, abundances of epibenthic predators such as shrimps, crabs, fish, and shorebirds were also lower at Sylt. Meiofauna was abundant on both shores, but differed in taxonomic composition. Several major taxa were represented in fairly equal proportions of individual numbers on the well-oxygenated Sylt shore, while nematodes strongly dominated the assemblage at Rømø. Thus, on cold-temperate, highly dynamic intermediate shores with high wave energy and subject to erosion, the "small food web" dominates. Organisms are agile and quickly exploit fresh organic material. Larger organisms and nematodes abound under stable, dissipative and accreting shore conditions, where some food materials may accumulate and zoomass builds up to support numerous visitors from higher trophic levels.
\end{abstract}

Communicated by H.-D. Franke

I. Menn (

Alfred-Wegener-Institut für Polar und Meeresforschung,

Wattenmeerstation Sylt, 25992 List, Germany

e-mail:imenn@awi-bremerhaven.de

Tel.: +49-4651-956111, Fax: +49-4651-956200
Keywords Sandy shore · Food web · Wave energy • Beach morphology

\section{Introduction}

Exposed sandy shores are often considered to be merely an edge of the sea or the land, but they also constitute an important ecotone with food chains based on decomposers, grazers and suspension feeders (McLachlan 1981; McLachlan et al. 1981a). High wave energy renders beaches inhospitable for many benthic species, but at the same time transforms a physical interface into a productive ecosystem. Exposed sandy shores are usually characterized by surf and epipsammic diatoms as main producers, while attached macroalgae are missing. In addition to microalgae, the food web is based on dissolved and particulate organic matter such as detritus and carrion, with the latter being of minor importance (Steele et al. 1970; McLachlan et al. 1981b; Brown and McLachlan 1990) except when marine mammals are stranded. Two partially separated food webs are based on these energy sources. The "small food web" consists of bacteria, protists and meiofauna. The main components of the "large food web" are macrobenthos and epibenthic predators such as shrimps, crabs, fishes and shorebirds. Both food webs are important in processing the organic materials washed ashore from the sea to which most production is returned (McLachlan 1981, 1983). The presence of these food web components and their relative importance in the system differ between beach types (Brown and McLachlan 1990). Two main types are distinguished, interface beaches and self-sustaining beach and surf zone systems. The former have no surf zone and no primary producers. Their interstitial biota are far more important than the macrofauna and they depend on marine inputs. The latter are characterized by well developed surf zones with significant primary production and a well developed, large food web. Such beaches are selfsustaining, i.e. they do not depend on offshore marine inputs. 
The vicinity of two exposed sandy shores divergent in morphodynamics, provided the opportunity to assess the effects of eroding and accreting conditions on the food web structure on cold-temperate shores in the North Sea. The eroding shore is coarse-grained, steep-profiled and receives high wave energy, while the accreting shore is fine-grained, flat-profiled and receives less wave energy. The former resembles dynamic intermediate beach types, and the latter a dissipative beach (Short and Wright 1983). A comprehensive approach included parameters of food supply (chorophyll $a$, particulate organic carbon, $\mathrm{C} / \mathrm{N}$ ratio and organic content as loss-on-ignition), meio-, macro- and epibenthos, and shorebirds. Concentrations of dissolved inorganic nutrients in interstitial and surf waters were determined as an indication of mineralization. In particular, the following questions were studied: What are the implications of shore morphology on food availability for the benthic fauna, on the composition of the meio- and macrofauna assemblage, and, finally, on visiting crabs, fish and birds?

\section{Methods}

Study sites

The study was conducted on shores of the exposed western sides of the neighbouring barrier islands of Sylt (Germany) and $\mathrm{R} \emptyset \mathrm{m} \varnothing$ (Denmark) in the eastern North Sea (Fig. 1). The tides are semidiurnal with a mean range of $1.8 \mathrm{~m}$, and neaps and springs are almost equal. Waves varied during the study period between a maximum height of $3 \mathrm{~m}$ with a period of $9 \mathrm{~s}$ and a minimum height of $0.1 \mathrm{~m}$ with a period of $4 \mathrm{~s}$. Mean wave height was $0.7 \pm 0.5 \mathrm{~m}$ (Amt für ländliche Räume Husum, Seegangsstatistik 1999, unpublished). Salinity was in the range of $27-33 \%$ psu. The average water temperature of this cold-temperate region is $4^{\circ} \mathrm{C}$ in winter and $15^{\circ} \mathrm{C}$ in summer.

Sylt projects some $5 \mathrm{~km}$ further seaward than $\mathrm{R} \emptyset \mathrm{m} \varnothing$ and the beach has retreated 1-2 m per year in the last century, while the Røm $\varnothing$ beach was progressing seaward during the same time period (Dette and Gärtner 1987; Bartholdy and Pejrup 1994). The eroding Sylt shore has a steep beachface (slope of $2-4^{\circ}$ ) and intermittent sand bars parallel to the beach at a horizontal distance of about $200 \mathrm{~m}$ from the mean low-water line (Fig. 2). Further offshore, the profile is rather steep with the $6 \mathrm{~m}$ depth contour within $1 \mathrm{~km}$ of the shoreline. The sediment on the Sylt shore is coarse to medium [median diameter $(\mathrm{Md})=0.56 \pm 0.33 \mathrm{~mm}$; Wentworth grade classification], moderately well sorted [quartile deviation $(\mathrm{QD})=0.56 \pm$ $0.18 \phi$ (phi); sorting classes (see Gray 1981)], and devoid of a
Fig. 1 Study sites $(\rightarrow)$ on the barrier islands of Sylt (Germay) and Røm $\varnothing$ (Denmark) in the eastern North Sea. Shading indicates different water depths $(>10 \mathrm{~m},>6 \mathrm{~m}$, $>0 \mathrm{~m}$ : intertidal flats)

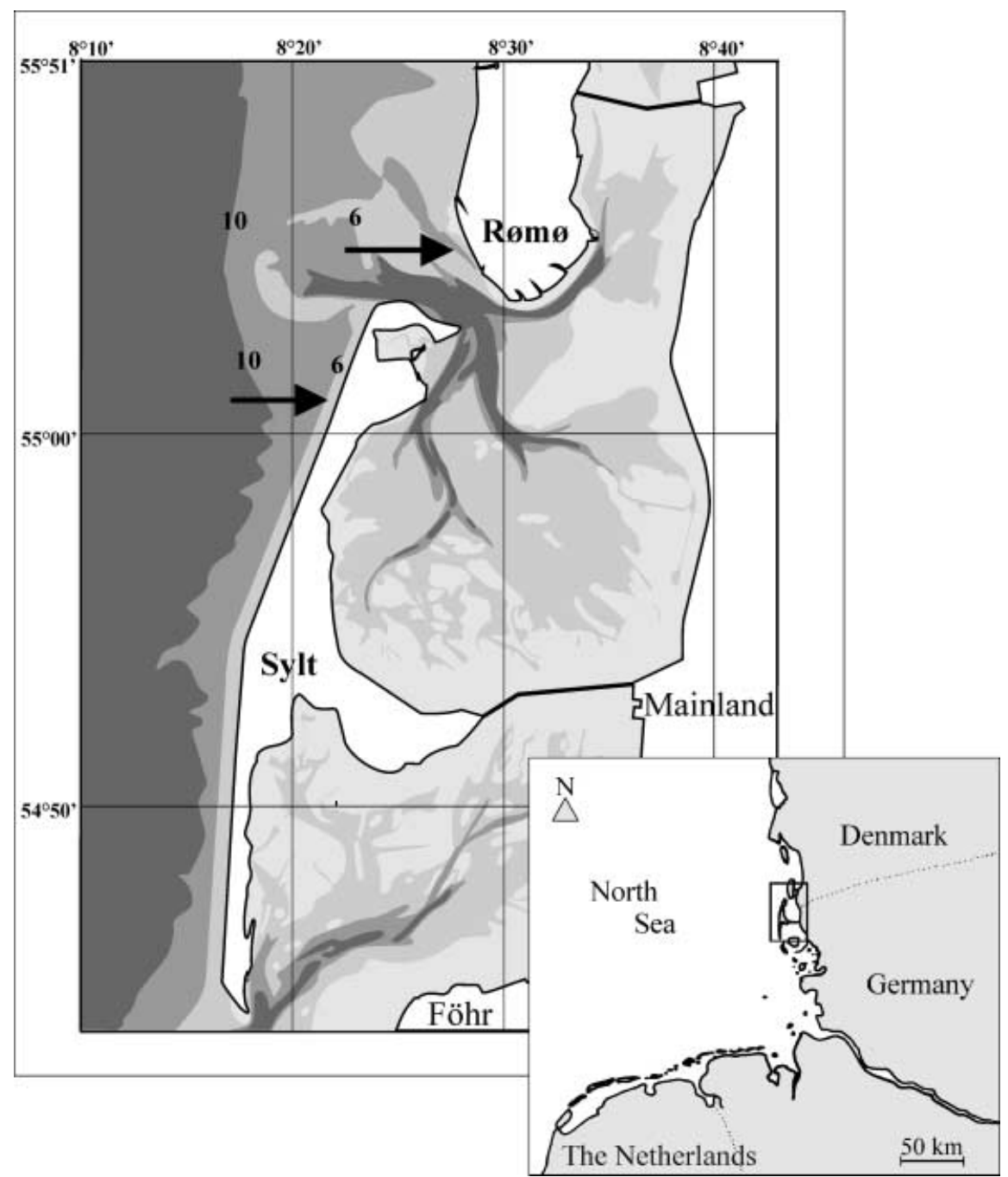


Fig. 2 Schematic profiles across the Sylt and Røm $\varnothing$ shore including sampling positions: 1 = mid-shore [midway between mean high $(\mathrm{MHW})$ and low water line $(M L W)]=0 \mathrm{~m}$ depth, $2=$ mean low water (0.9 $\mathrm{m}$ depth), $3=1.4 \mathrm{~m}$ depth, $P N=1.9 \mathrm{~m}$ depth, $4=7 \mathrm{~m}$ depth, dredge $=3-8 \mathrm{~m}$ depth. Core sampling of meio- and macrobenthos: position 1-4; sediment sampling for determination of particulate organic matter: position 1-3; sediment sampling for determination of chl $a$ and sampling of interstitial waters for inorganic nutrients: position 2; sampling of surf waters for chl $a$ and inorganic nutrients: position 3 . $P N=$ push-net sampling, dredge $=$ dredge sampling. Shading refers to grain size: light grey coarse to medium sand, dark grey medium to fine sand. Terminology of different zones across the shore is according to Short (1999)
Sylt: eroding, intermediate shore with high wave energy

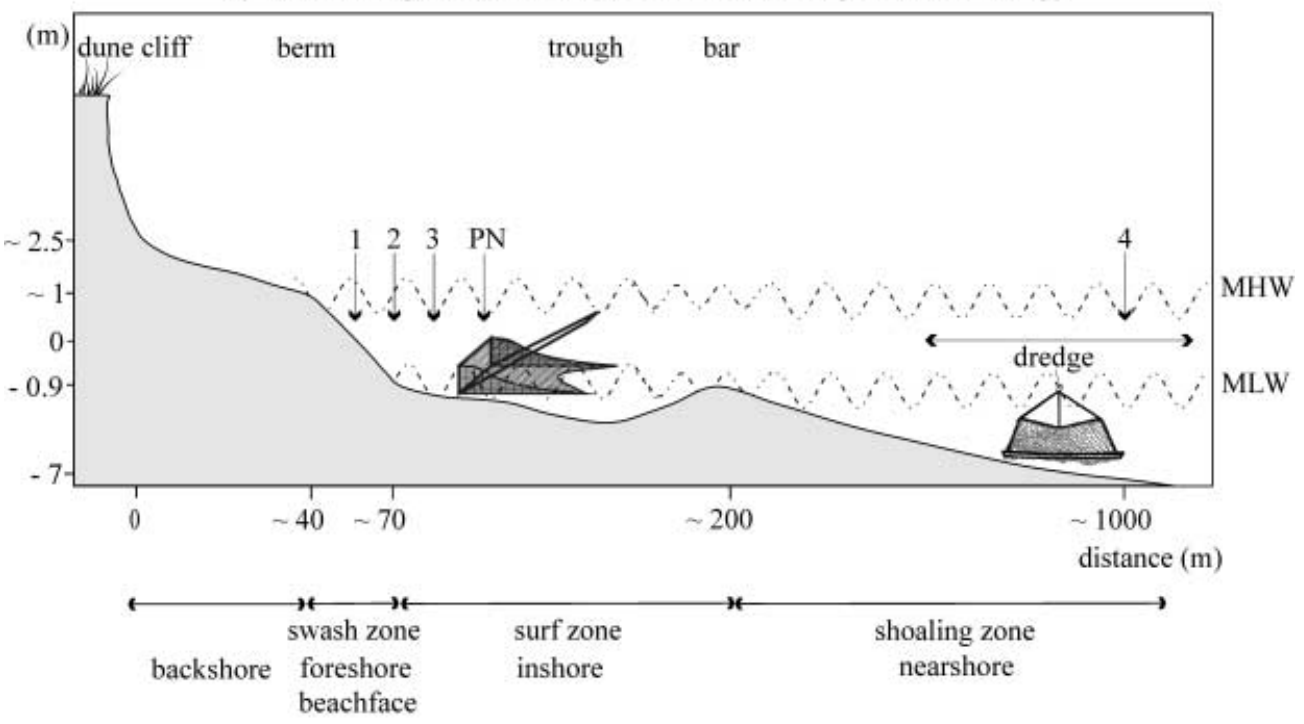

Rømø: accreting, dissipative shore with low wave energy

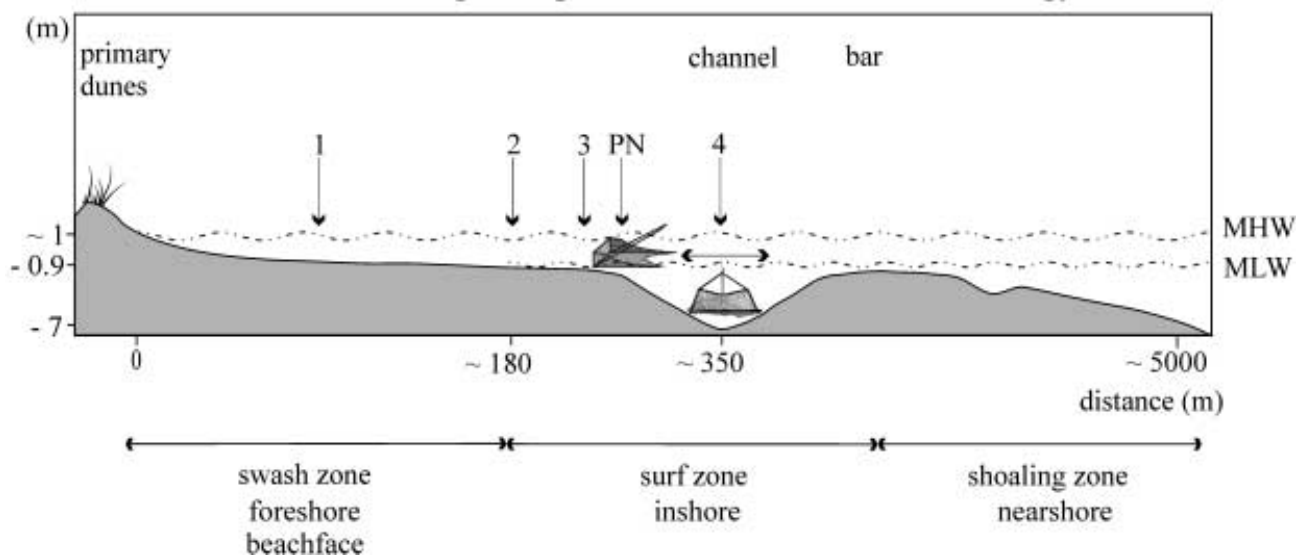

blackish sulphide layer during the whole year. In contrast, the accreting Rom $\varnothing$ shore has a wide and flat beachface $\left(\right.$ slope $=1^{\circ}$ ) and a trough of 6-8 $\mathrm{m}$ depth directly seaward of the mean low-water line. The latter is part of the ebb tide delta of the tidal inlet between Sylt and Rømø. Further offshore, the profile is flat, with the $6 \mathrm{~m}$ depth contour occurring $5 \mathrm{~km}$ west of the shoreline. Much wave energy dissipates on this broad and flat offshore profile, and may explain why the Røm $\emptyset$ beachface receives less wave energy than the Sylt beachface (summarizing data from K. Ahrendt, personal communication). The sediment at R $\varnothing \mathrm{m} \varnothing$ consists of medium to fine sand $(\mathrm{Md}=0.20 \pm 0.05 \mathrm{~mm})$, is well sorted $(\mathrm{QD}=0.33 \pm$ $0.09 \phi)$, and based on an annual average there is a blackish sulphide layer beginning at $8 \mathrm{~cm}$ sediment depth. According to the beach classification of Short and Wright (1983), the morphodynamic state of the Sylt shore resembles intermediate types ("longshore bar-through" and "rhythmic bar and beach" during winter; "transverse bar and rip" and "low tide terrace" during summer). These are the most dynamic beach types (Short 1999) and periodic beach nourishments at Sylt enhance these dynamics, resulting in a non-equilibrium morphodynamic state. The Røm $\varnothing$ shore resembles a dissipative type and was morphologically constant throughout the study period.

\section{Sampling}

To determine the chlorophyll $a(\operatorname{chl} a)$ content in surf waters and in the sediment, samples were collected on both shores in July and August 1999 (Fig. 2). Surf water samples were taken at $1.4 \mathrm{~m}$ water depth, and $100 \mathrm{ml}$ was filtered (Whatman GF/F glass microfibre filters) for analysis. Sediment samples of $2 \mathrm{~cm}$ depth were collected at the mean low-water line using cores of $5 \mathrm{~cm}^{2}$ and $2 \mathrm{~cm}^{2}$ cross area at Sylt and Røm $\varnothing$, respectively. Surveys were conducted during low tide around midday. At each shore on each sampling occasion, ten replicates were taken along $1 \mathrm{~km}$ of shoreline, with the exception of sediment sampling in July when 20 replicates were collected. Chl $a$ was measured spectrophotometrically after acetone extraction, and chl $a$ concentrations were calculated according to Lorenzen (1967).

For particulate organic matter, particulate organic carbon and particulate nitrogen in the sediment, samples were taken in August 1999 at three water depths (positions 1 to 3; Fig. 2). At each position, eight replicates of surface sediment samples were taken along $1 \mathrm{~km}$ of shoreline. Carbon and nitrogen analyses were carried out using a $\mathrm{C} / \mathrm{N}$ analyser (Heraeus Elementar Vario EL). Organic matter in the sediment was further measured as loss-on-ignition (LOI) after $12 \mathrm{~h}$ at $550^{\circ} \mathrm{C}$, and is expressed as a percentage of sediment dry weight. Sampling was done in April 1999, collecting sediment samples at three water depths, as mentioned above, each with six replicates on both shores. 
To assess nutrient concentrations in surf and interstitial waters, parallel samples were taken at Sylt and Røm $\varnothing$ in July and August 1999. Sampling was conducted during low water by taking surf water samples at $1.4 \mathrm{~m}$ depth and interstitial water samples at mean low-water line (Fig. 2). Interstitial water was extracted from surface sediments $(5-10 \mathrm{~cm}$ depth) through ceramic cups and sucked into evacuated glass bottles (M. van Katwijk, personal communication). During both occasions, replicates (July surf water: 15, interstitial water: 20; August surf and interstitial water: 10) were collected along $1 \mathrm{~km}$ of shoreline. Nutrient analyses (ammonium, nitrite, nitrate, phosphate and silicate) were carried out following the methods described by Grasshoff et al. (1983). Due to very low nitrite concentrations $\left(<0.3 \mu \mathrm{mol} \mathrm{l}^{-1}\right)$ in relation to nitrate $\left(>1 \mu \mathrm{mol} \mathrm{l}^{-1}\right)$, both were pooled to nitrite plus nitrate $\left(\mathrm{NO}_{\mathrm{x}}\right)$ concentrations.

Meio- and macrofauna were sampled on both shores at four positions along a transect from mean tide line to $7 \mathrm{~m}$ depth (Fig. 2). The transects were replicated six times, evenly distributed along $1 \mathrm{~km}$ of shoreline. At each position one core for meiofauna (cross area: $10 \mathrm{~cm}^{2}$ ) down to a sediment depth of $30 \mathrm{~cm}$ was taken and four cores for macrofauna (cross area: $50 \mathrm{~cm}^{2}$ ) down to a depth of $20 \mathrm{~cm}$, which were pooled to $200 \mathrm{~cm}^{2}$. With respect to temporal variability, sampling was repeated four times: in April, July and October 1998 and in January 1999. The meiofauna were extracted from the sediment using the SMB method of Noldt and Wehrenberg (1984; sieve mesh size: $63 \mu \mathrm{m}$ ), sorted into major taxa, and counted. Due to their very low abundances, nemerteans, oligochaetes, gastrotrichs and bivalves are summarized under "others". Macrofauna samples were sieved (1 mm mesh size), the animals sorted alive, counted and identified to species level whenever possible. The abundance category "others" comprises decapods, nemerteans, cumaceans and gastropods. A more detailed description of meio- and macrobenthos sampling on both shores is reported in Menn (2002).

"Small" epibenthos was collected using a Riley push-net (Eleftheriou and Holme 1984) of $1.5 \mathrm{~mm}$ mesh size, and a $1.90 \mathrm{~m}$ net bag kept open by a rectangular frame of $1.50 \times 0.30 \mathrm{~m}$. The survey was carried out in July and August 1999 with ten hauls of $70 \mathrm{~m}$ length per shore during each sampling survey. In July sampling was conducted at sunrise and nightfall, in August during day and night. All hauls were taken around low tide, and arranged alongshore at $1.90 \mathrm{~m}$ water depth, with respect to mid-shore $=0 \mathrm{~m}$ depth (duration of each haul was $\sim 1$ min; Fig. 2). All organisms in the net were counted and identified to species level whenever possible. Sometimes the entire net was filled with green algae. In such cases, half of the content was sorted for species, and counts of individuals were multiplied by two. Then the entire content was sorted for rare species.

"Large" epibenthos was sampled with a traditional oyster dredge of $1 \mathrm{~cm}$ mesh size. The dredge had a wrought-iron blade of $1 \mathrm{~m}$ in width at its lower edge. The $0.5 \mathrm{~m}$ long net bag was kept open by a rectangular frame of $1 \times 0.5 \mathrm{~m}$. The survey was carried out in June and July 1999 by taking 12 hauls of 500 m length on both shores during each sampling. The hauls were collected at 3-8 m water depth around low tide in the morning (Fig. 2). All organisms in the net were counted and identified to species level whenever possible. Besides living epibenthos, the dredge content was composed of shell gravel with some stones, and occasionally with clumps of clay or peat. Sometimes shell gravel or Lanice conchilega tubes filled the entire net bag. In these cases, half of the total content was sorted for species, and counts of individuals were multiplied by two. The entire content was then sorted for rare species. Because of their small size relative to the mesh size of the dredge, amphipods and mobile polychaetes were disregarded. Macroscopic epigrowth on organisms was also recorded, counted as a colony and added to the total abundance of "large" epibenthos. The abundance category "Moll/Echinod" comprises molluscs and echinoderms, and "Cnidar/Bryoz" comprises cnidarien and bryozoen colonies. Flatfish (mostly $<5 \mathrm{~cm}$ in length) in dredge and push-net samples were summarized as "juvenile flatfish". These dredge and push-net samples are regarded as semiquantitative, because dredges sometimes bounce up and down on the bottom (Field 1970). Efficiency of push-net samples may be low with respect to Carcinus maenas, because this crab may quickly burrow into the sediment when approached by a net (Hermann et al. 1998).

During preliminary studies, resting and feeding birds were recorded on both shorelines, indicating sanderlings (Calidris alba) as the most numerous migrants on the Sylt and $R \varnothing m \emptyset$ shores. To get an impression of avian predation pressure, feeding sanderlings were counted along $1 \mathrm{~km}$ of shoreline. Counts were related to shoreline instead of area, because sanderlings trail the water's edge and forage whenever a wave has receded (Myers et al. 1980; Roberts and Evans 1993). A survey was carried out in May 1999, because many sanderlings visit the Wadden Sea during spring migration and peak in mid- to late May (Meltofte et al. 1994). On five days with similar weather conditions the birds were counted every 15 min during $5 \mathrm{~h}$ around low tide when the intertidal area of the shores was exposed ( $4 \mathrm{~h}$ before and $1 \mathrm{~h}$ after low tide). Additionally, this time range was chosen because McLachlan et al. (1980) reported sanderlings feeding throughout the day and A. Crowe (personal communication) reported a main feeding time around low tide.

The main thrust of this study was on meio- and macrofauna dwelling in the sediment (Menn 2002). All other measurements reported are at a lower level of effort. They are presented here to provide a comprehensive picture of the diverging food webs of the two shores for which the infauna may serve as an indicator.

\section{Statistics}

A one-way ANOVA (analysis of variance) was used to test for differences in abundances of meio-, macro- and epibenthos as well as in concentrations of chl $a$, particulate organic matter and inorganic nutrients between the shores. To test for homoscedasticity of variances, Cochran's test was used, and data of the dependent variables were transformed once (square root transformation of macrobenthos individual densities). When variances were not homogeneous despite the transformation, Wilcoxon, Mann and Whitney's non-parametric $U$-test (Sachs 1984) was used (statistical advice from C. Hennig, Department for Mathematics, University of Hamburg). Statistical significance was assumed at $P<0.05$ for ANOVA and $U$-test, and at $P<0.025$ for multiple $U$-tests (comparison of inorganic nutrient concentrations between and within the shores; Bonferroni procedure for multiple comparisons; Sokal and Rohlf 1995). To test for overall differences in meio- and macrofauna abundances between shores, data for the four transect positions each with six replicates and of the four sampling surveys were pooled $(n=96)$. Temporal and spatial variability of the infauna is presented in Menn (2002). Different sampling occasions of chl $a$, inorganic nutrients and epibenthos (e.g. June, July, August, sunrise, nightfall, day, night) were analysed separately. The same was done with sedimentary $\mathrm{C} / \mathrm{N}$ and organic matter as LOI with three sample positions at different water depths, each with eight and six replicates, respectively. In "large" epibenthos, the hauls from within the depth range 3-8 $\mathrm{m}$ were pooled $(n=12)$ for analysis. For testing differences in abundances of feeding sanderlings along the shorelines, mean abundance per counting day was calculated and used in the analysis.

\section{Results}

Chlorophyll $a$, particulate organic matter and inorganic nutrients

Chl $a$ values in surf waters showed no significant differences between the Sylt and the Rømø shore in July and August, while the sediment at Røm $\varnothing$ contained significantly higher chl $a$ concentrations than that at Sylt in both months (Fig. 3). Particulate organic carbon and C/N 

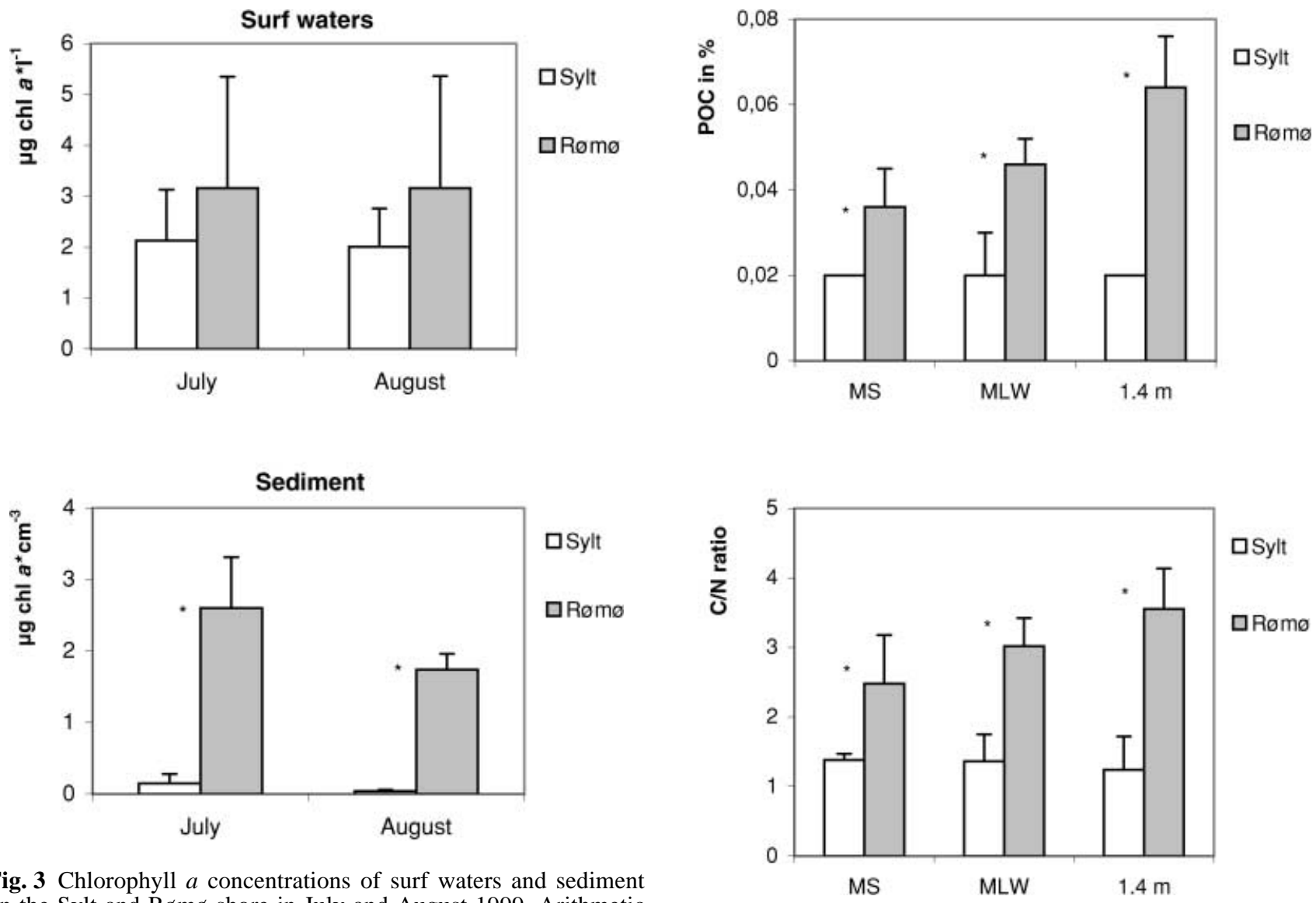

Fig. 3 Chlorophyll $a$ concentrations of surf waters and sediment on the Sylt and Rømø shore in July and August 1999. Arithmetic means with standard deviations of ten replicates per sampling occasion (with the exception of sediment sampling in July: $n=20$ ). Asterisks denote significant differences between shores within each sampling survey; both $U$-test, $P<0.001, d f=1$

ratios were significantly higher on the Røm $\varnothing$ than on the Sylt shore at all sample positions (Fig. 4). Organic content LOI was also higher at Røm $\varnothing$ than at Sylt at all positions $[\mathrm{R} \varnothing \mathrm{m} \varnothing /$ Sylt $(\%)$ : mid shore $0.19 \pm 0.08 / 0.13 \pm 0.03$; mean low water $0.24 \pm 0.1 / 0.16 \pm 0.04 ; 1.4 \mathrm{~m}$ depth $0.23 \pm$ $0.07 / 0.16 \pm 0.06$; all $U$-test, $P<0.05, d f=1]$.

In surf waters no differences were detected in phosphate and silicate concentrations between the shores during both sampling surveys. Ammonium concentration showed no difference in July, but were significantly higher at Rømø than at Sylt in August (Fig. 5). Conversely, nitrite plus nitrate $\left(\mathrm{NO}_{\mathrm{x}}\right)$ concentrations in surf waters were lower at Røm $\varnothing$ during both sampling occasions. In interstitial waters, concentrations of all nutrients differed between the shores in July and August (Fig. 5). Phosphate, silicate and ammonium were significantly higher at Rømø than at Sylt, while $\mathrm{NO}_{\mathrm{x}}$ showed the opposite pattern. Nutrient concentrations in interstitial waters were higher than in surf waters on both shores during both sampling periods (Fig. 6). Exceptions, with no difference between interstitial and surf waters, were ammonium (July, Sylt) and $\mathrm{NO}_{\mathrm{x}}$ (August, Sylt).

Fig. 4 Particulate organic carbon $(P O C)$ and $\mathrm{C} / \mathrm{N}$ ratio of sediment on the Sylt and Rømø shore in August 1999. Arithmetic means with standard deviations calculated over eight replicates per position. $M S$ mid-shore, $M L W$ mean low water, $1.4 \mathrm{~m}$ depth line. Asterisks denote significant differences between shores; all $U$-test, $P<0.01, d f=1$

\section{Meio- and macrofauna}

Total meiofaunal abundance did not differ between the Sylt and the Røm $\varnothing$ shore, but there were differences in terms of individual numbers of major taxa (Fig. 7). Abundances of nematodes were significantly higher at Rømø than at Sylt, while the reverse was true for abundances of plathelminths, copepods, ostracods and acarids (all $U$-test, $P<0.001, d f=1$ ). The abundance of polychaetes and minor taxa showed no differences between the two shores. Nematodes $(84 \%)$ clearly dominated the meiofaunal assemblage on the Røm $\varnothing$ shore, while on the Sylt shore polychaetes (17\%), plathelminths (24\%), nematodes (22\%) and copepods (26\%) comprised fairly equal proportions. The total abundance of macrofaunal organisms was significantly higher at Røm $\varnothing$ than at Sylt (one-way ANOVA, $P<0.0001, F=63.22, d f=1$; Fig. 7). This was mainly caused by higher abundances of polychaetes and bivalves on the $\mathrm{R} \emptyset \mathrm{m} \emptyset$ shore. Isopods occurred only at Sylt (all $U$-test, $P<0.0001, d f=1$ ). A detailed description of the meio- and macrofaunal communities is given in Menn (2002). 
Fig. 5 Inorganic nutrient concentrations of surf and interstitial waters at Sylt in contrast to Rømø in July and August 1999 presented as arithmetic means with standard deviations calculated over replicates per sampling survey (July: surf water $n=15$, interstitial water $n=20$; August: both $n=10) . N O_{x}$ nitrite plus nitrate. Asterisks denote significant differences between shores within each sampling occasion; all $U$-test, $P<0.025$, $d f=1$. Note the difference in scale between surf and interstitial water
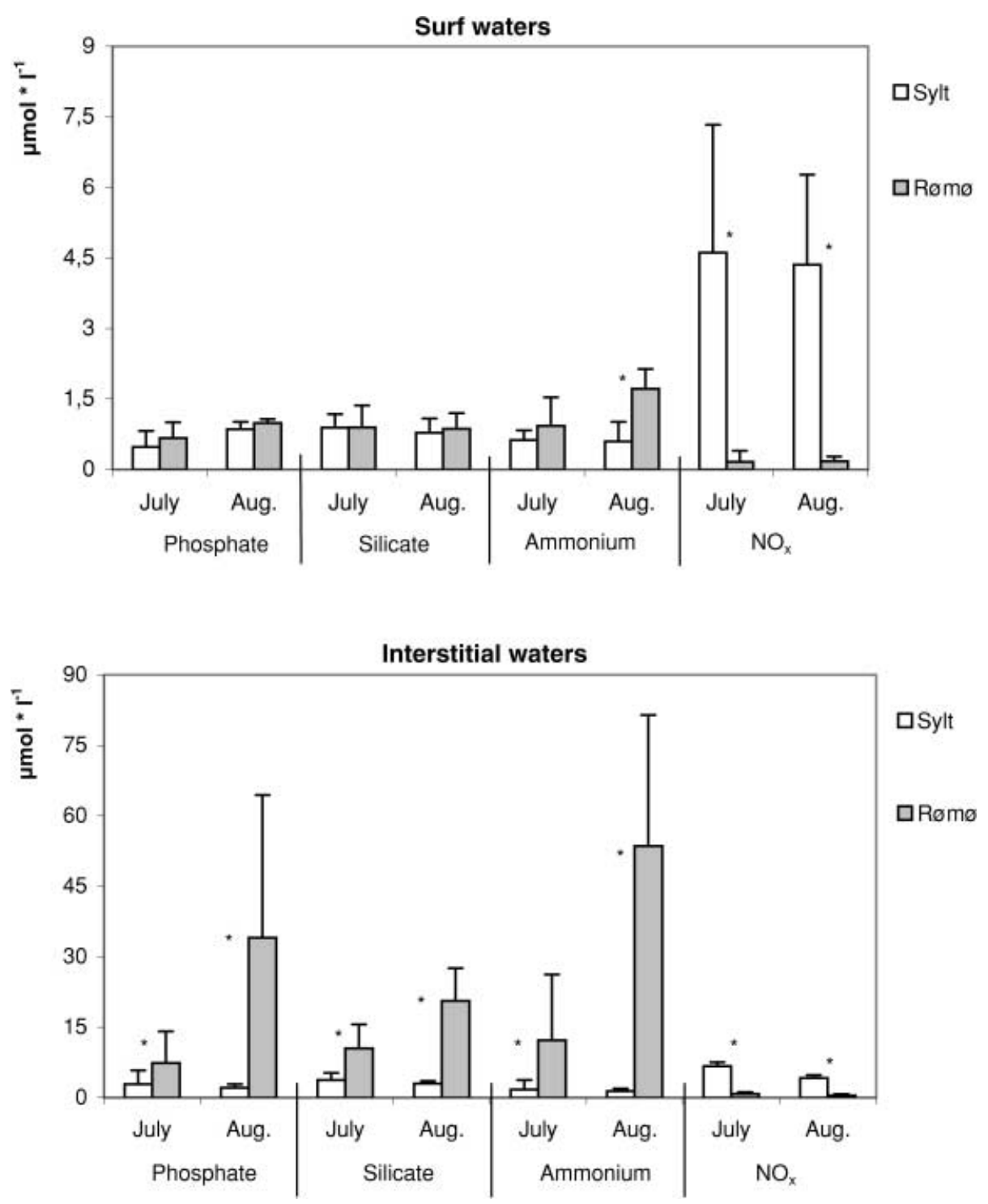

Epibenthos and sanderlings

Total abundance of "small" epibenthos was significantly higher on the Røm $\emptyset$ than on the Sylt shore during both sampling occasions in July and in day-sampling in August (Fig. 8). Night-sampling in August showed no statistically significant differences between the shores. On both shores Nilsson's pipefish (Syngnathus rostellatus), sand goby (Pomatoschistus minutus), brown shrimp (Crangon crangon) and shore crab (Carcinus maenas) were the dominant fish and crustacean species. The differences between the shores in July were mainly brought about by sand goby ( $P$. minutus) and brown shrimp (C. crangon). In August in day-sampling higher crustacean densities, particularly brown shrimp, at Rømø than at Sylt caused the difference in total epibenthos abundance between the shores (all $U$-test, $P<0.05, d f=1$ ). All other taxa showed no statistically significant differences in abundances between the shores.
The total abundance of "large" epibenthos was significantly higher on the Røm $\varnothing$ than on the Sylt shore in June and July (Fig. 9). Densities of molluscs/echinoderms, barnacles and cnidariens/bryozoans were higher at Rømø than at Sylt during both sampling occasions. Decapod abundance was only significantly higher at Rømø than at Sylt in July. However, decapod abundance in June, without $C$. crangon, revealed a significant difference between the shores. The ranking of dominant species in each taxa was similar at Rømø and Sylt (Table 1).

Feeding sanderlings (Calidris alba) showed significantly higher abundances on the Rømø than on the Sylt shoreline ( $U$-test, $P<0.01, d f=1$; Fig. 10 ).

\section{Discussion}

The presence of food web components on sandy shores differs between beach types due to different shore mor- 
Fig. 6 Inorganic nutrient concentrations of surf in contrast to interstitial waters on the Sylt and Røm $\varnothing$ shore in July and August 1999 presented as arithmetic means with standard deviations calculated over replicates per sampling (July: surf water $n=15$, interstitial water $n=20$, August: both $n=10$ ). Surf surf waters, interstitial interstitial waters. Asterisks denote significant differences between interstitial and surf waters within shores and within each sampling survey; all $U$-test, $P<0.025, d f=1$. Note the difference in scale between Sylt and Røm $\varnothing$
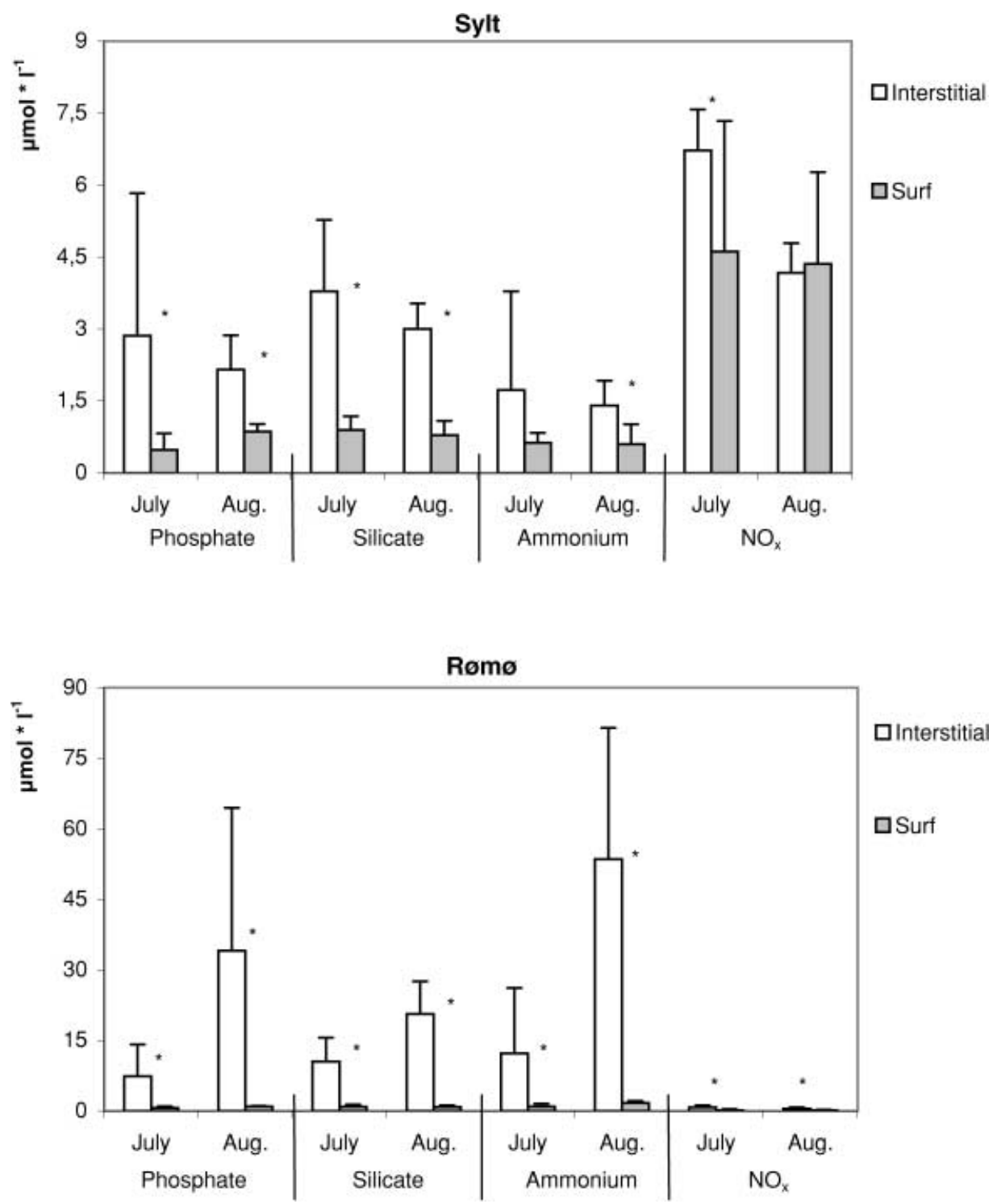

phology and associated grain size and wave energy (Fig. 11).

\section{"Large food web" \\ (macrobenthos-epibenthos-shorebirds)}

Food sources for the macrobenthos on sandy shores are surf and epipsammic diatoms, particulate and dissolved organic matter, detritus and carrion (Brown and McLachlan 1990). However, the major food available to the macrobenthos may differ between the studied shores as a result of their different morphodynamic states. The Røm $\varnothing$ shore apparently stores food sources in the sediment, which is indicated by a higher amount of particulate organic carbon and chl $a$ in the sediment at $\operatorname{Røm} \varnothing$ than at Sylt. Less wave energy and finer sand grains at Røm $\varnothing$ may enhance the accumulation of organic material from the surf waters. Furthermore, higher $\mathrm{C} / \mathrm{N}$ ratios indicate a higher amount of refractive material at $\mathrm{R} \varnothing \mathrm{m} \varnothing$ than at
Sylt. In contrast, at Sylt high hydrodynamics and erosion may prevent any storage of organic carbon in the sediment. However, this shore may filter higher volumes of sea water than the Røm $\varnothing$ shore due to coarser sediment, steeper profile and higher wave energy, resulting in higher fluxes of particulate organic matter on this shore, despite similar chl $a$ concentrations (and probably particulate organic matter) in the surf waters on both shores. Thus, the sediment at $\mathrm{R} \varnothing \mathrm{m} \emptyset$ is probably a richer food source for deposit feeders. This is supported by a higher abundance of macrofauna on this shore. Cammen (1982) also assumed that fine-grained sediment was a richer food source for deposit feeders. In contrast, higher fluxes of particulate organic matter at Sylt may support filter feeders, as has been shown on shores in South Africa (McLachlan 1981; McLachlan et al. 1981a). However, compared with Rømø, the Sylt macrofauna is impoverished. Physical disturbance by high wave energy is proposed as the major limitation for the macrofauna on the intermediate Sylt shore, while food availability may not 
Fig. 7 Total meio- and macrofaunal abundance and abundance of major taxa on the Sylt and Røm $\varnothing$ shore. Arithmetic means of four transect positions each with six replicates and of four sampling surveys $(n=96)$. "Others" includes nemerteans, oligochaetes, gastrotrichs and bivalves in meiofauna; and decapods, nemerteans, cumaceans and gastropods in macrofauna. Plathel. plathelminths
Fig. 8 Total abundance of "small" epibenthos per $70 \mathrm{~m}$ push-net haul on the Sylt and Røm $\varnothing$ shore in July and August presented as arithmetic means with standard deviations of ten hauls at $1.90 \mathrm{~m}$ water depth. Asterisks denote significant differences between shores within each sampling; all oneway ANOVA, $P<0.05, d f=1$, July: sunrise $F=13.61$, nightfall $F=55.97$, August: daytime $F=5.23$
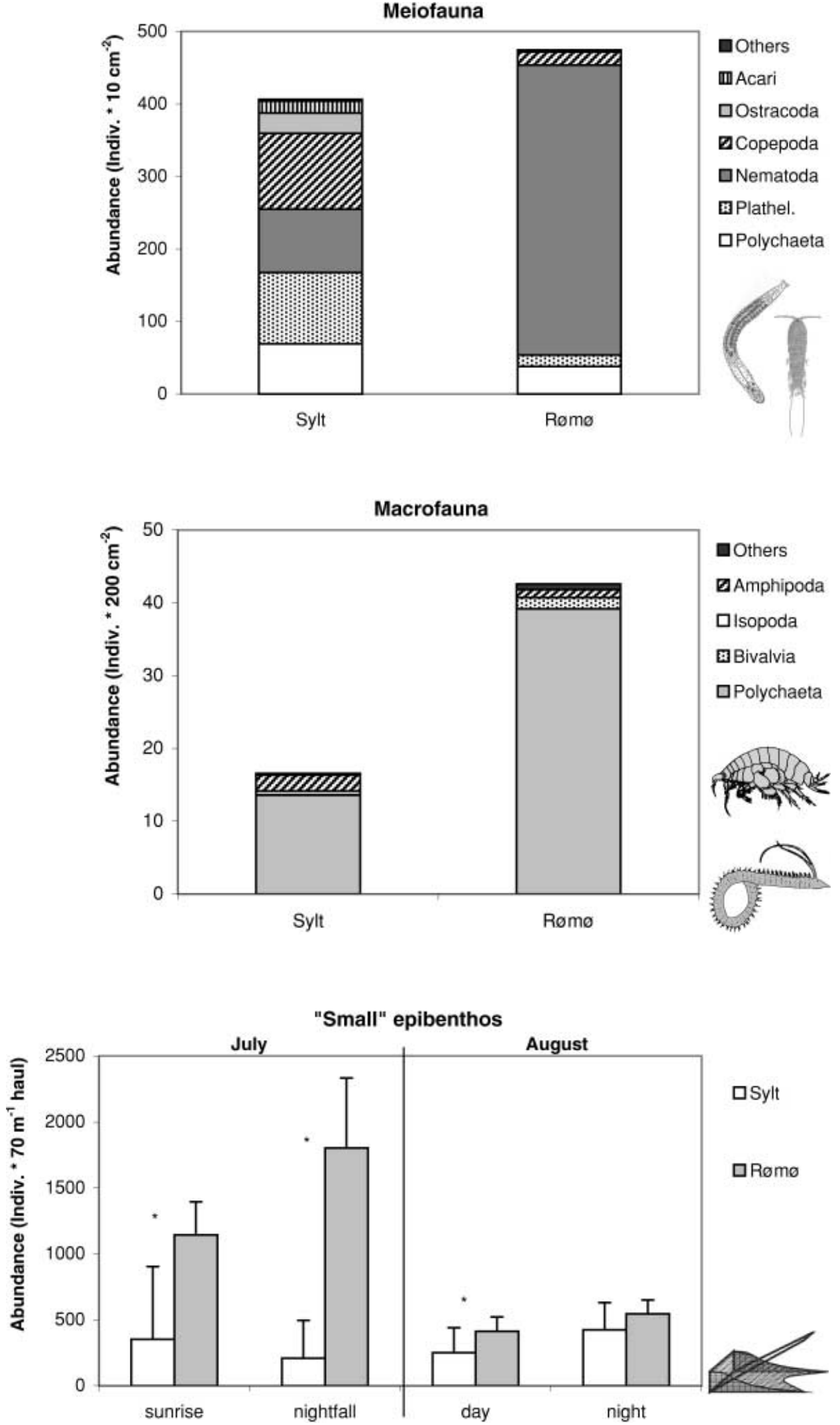
Fig. 9 Total abundance and abundance of major taxa of "large" epibenthos per $500 \mathrm{~m}$ dredge haul on the Sylt and Rømø shore in June and July presented as arithmetic means with standard deviations of 12 hauls within 3-8 $\mathrm{m}$ water depth. Moll/Echinod total of Mollusca and Echinodermata, Cnidar/Bryoz total of cnidarian and bryozoen colonies. June \# indicates crustacean abundances without Crangon crangon. Asterisks denote significant differences between shores within each sampling survey; total abundance: both $U$-test, $P<0.05, d f=1$; taxa abundance: all $U$-test, $P<0.01, d f=1$
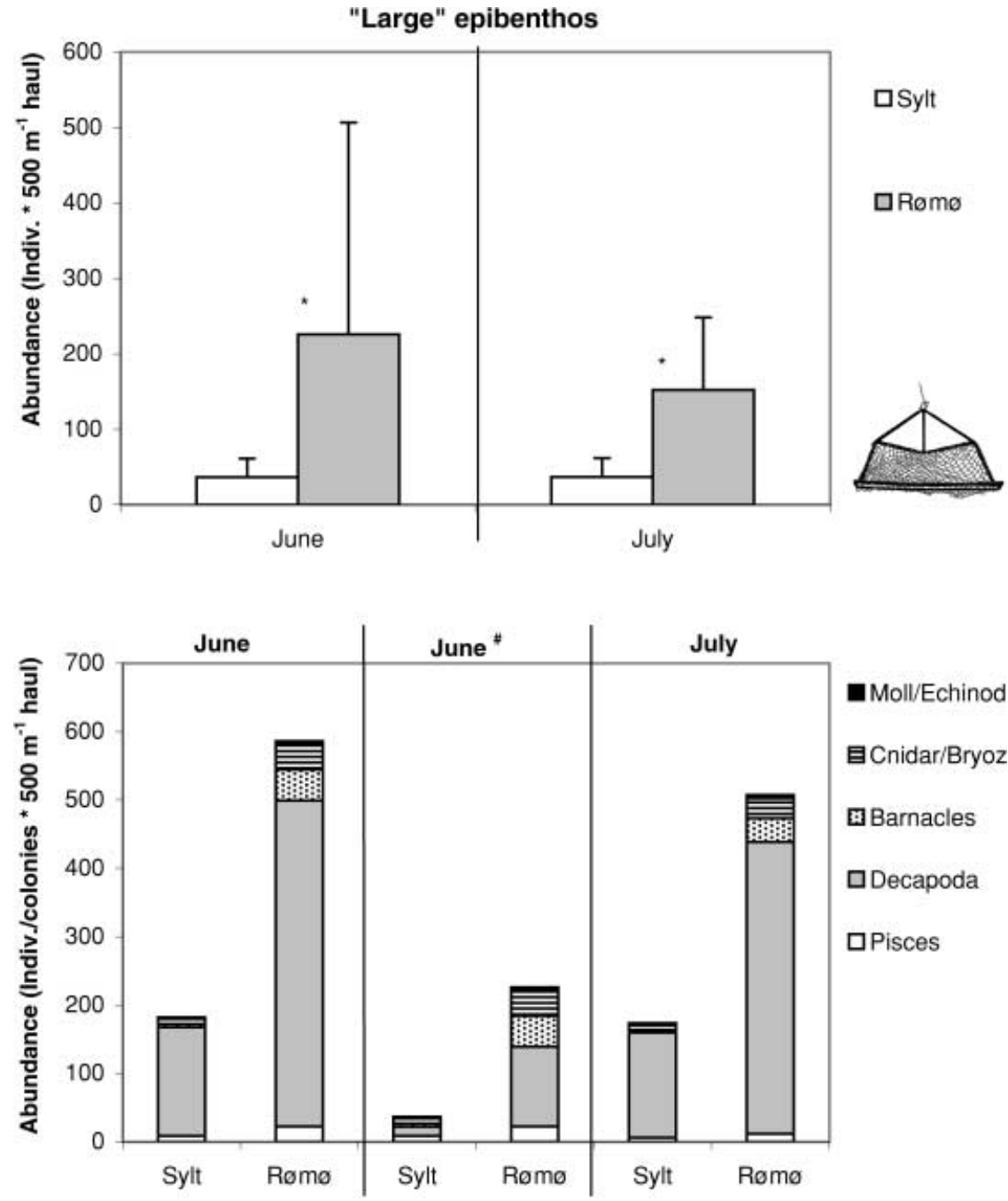

Table 1 Ranking of species of "large" epifauna on the Sylt and the Rømø shore in June and July 1999. Species contributing $90 \%$ of the total abundance per taxa are listed

\begin{tabular}{|c|c|c|c|c|c|c|c|}
\hline Sylt June & $\%$ & Rømø June & $\%$ & Sylt July & $\%$ & Rømø July & $\%$ \\
\hline \multicolumn{8}{|l|}{ Pisces } \\
\hline $\begin{array}{l}\text { Juvenile flatfish } \\
\text { Pleuronectes platessa }\end{array}$ & $\begin{array}{l}55 \\
28\end{array}$ & $\begin{array}{l}\text { Juvenile flatfish } \\
\text { Syngnathus rostellatus } \\
\text { Sprattus sprattus } \\
\text { Pomatoschistus minutus }\end{array}$ & $\begin{array}{l}31 \\
20 \\
17 \\
12\end{array}$ & $\begin{array}{l}\text { Pleuronectes platessa } \\
\text { Juvenile flatfish }\end{array}$ & $\begin{array}{l}74 \\
13\end{array}$ & $\begin{array}{l}\text { Pleuronectes platessa } \\
\text { Merlangius merlangus } \\
\text { Sprattus sprattus } \\
\text { Pomatoschistus minutus }\end{array}$ & $\begin{array}{l}47 \\
13 \\
13 \\
10\end{array}$ \\
\hline \multicolumn{8}{|l|}{ Crustacea } \\
\hline \multicolumn{8}{|l|}{ Mollusca } \\
\hline & & $\begin{array}{l}\text { Macoma balthica } \\
\text { Cerastoderma edule }\end{array}$ & $\begin{array}{l}69 \\
19\end{array}$ & $\begin{array}{l}\text { Crepidula fornicata } \\
\text { Mytilus edulis }\end{array}$ & $\begin{array}{l}50 \\
50\end{array}$ & $\begin{array}{l}\text { Crepidula fornicata } \\
\text { Macoma balthica }\end{array}$ & $\begin{array}{l}65 \\
28\end{array}$ \\
\hline \multicolumn{8}{|l|}{ Cnidaria } \\
\hline \multicolumn{8}{|l|}{ Bryozoa } \\
\hline $\begin{array}{l}\text { Electra pilosa } \\
\text { Bowerbankia imbricata }\end{array}$ & $\begin{array}{l}50 \\
43\end{array}$ & $\begin{array}{l}\text { Electra pilosa } \\
\text { Bowerbankia imbricata }\end{array}$ & $\begin{array}{l}50 \\
43\end{array}$ & $\begin{array}{l}\text { Electra pilosa } \\
\text { Alcyonidium } \mathrm{sp} .\end{array}$ & $\begin{array}{l}75 \\
25\end{array}$ & $\begin{array}{l}\text { Electra pilosa } \\
\text { Alcyonidium } \mathrm{sp} .\end{array}$ & $\begin{array}{l}56 \\
24\end{array}$ \\
\hline
\end{tabular}


be a limiting factor, due to high fluxes of particulate organic matter on this shore. Accordingly, oxygen availability is unlikely to limit the macrofauna at Sylt. A negative correlation of macrofauna with strong hydrodynamics and unstable sediments has also been also reported, for example by Brown and McLachlan (1990), Christie (1976) and Lackschewitz and Reise (1998). While severe hydrodynamic turbulence seems to exclude filter feeders from cold-temperate shores, such popula-

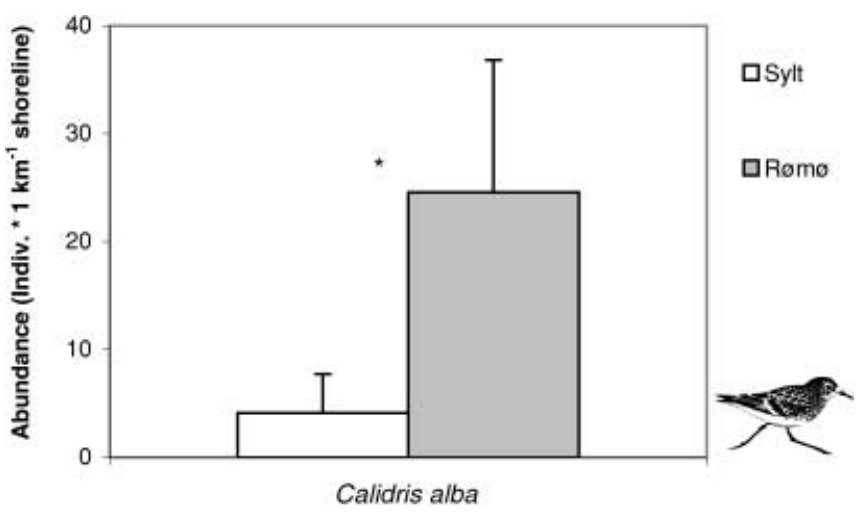

Fig. 10 Abundance of sanderlings (Calidris alba) along $1 \mathrm{~km}$ of shoreline on the Sylt and Rømø shore in May 1999 presented as arithmetic means with standard deviations of five counting days each with $5 \mathrm{~h}$ of counting. Asterisks denote significant differences between shores tions (e.g. surf clams Donax spp., hippoid crabs Emerita spp.) are able to cope with such conditions on warmtemperate to tropical shores (Steele 1976; McLachlan et al. 1981a). Apparently, this niche of agile filter feeders is not occupied in the eastern North Sea due to low temperature, which may restrict the mobility of these poikilotherme organisms. The same may be true for agile scavengers (e.g. Bullia spp.). Under low hydrodynamic conditions the benthic macrofauna of the nearshore zone also colonizes the beachface of cold-temperate shores.

The inshore zone of sandy shores may act as a feeding ground for epibenthic species and, especially for juvenile fish, as nursery areas rich in food (McIntyre and Eleftheriou 1968; Lasiak 1981; Brown and McLachlan 1990). The most abundant epibenthic predators at Sylt and Røm $\varnothing$ (brown shrimp, shore crab, sand goby, juvenile flatfish, pipefish) are opportunistic carnivores, mainly feeding on infauna selected on the basis of relative availability (Pihl 1985). Newly recruited individuals feed on zooplankton and, to some extent, on meiobenthos, while older stages feed on small macroinvertebrates such as epibenthic mysids and crustaceans, polychaetes, or bivalve siphons (Edwards et al. 1970; Mehner 1992; Pihl 1985; Hamerlynck and Cattrijsse 1994). The only exception in the study area was Nilsson's pipefish, which is mainly planktivorous (Hermann et al. 1998). Lower epibenthic abundances at Sylt than at Rømø are probably a result of low food availability. This may be indicated by an impoverished macrofauna at Sylt in contrast to Rømø,
Fig. 11 Food web structure on cold-temperate shores. Highly dynamic, intermediate shores with high wave energy and subject to erosion are characterized by high fluxes of organic material through the beach, but without storage of food sources in the sediment. On these shores the "small food web" of agile organisms dominates, while organic storage and the "large food web" is important on stable, dissipative and accreting shores. Arrows indicate flow of organic and mineralized substances

\section{Eroding intermediate shore with high wave energy}

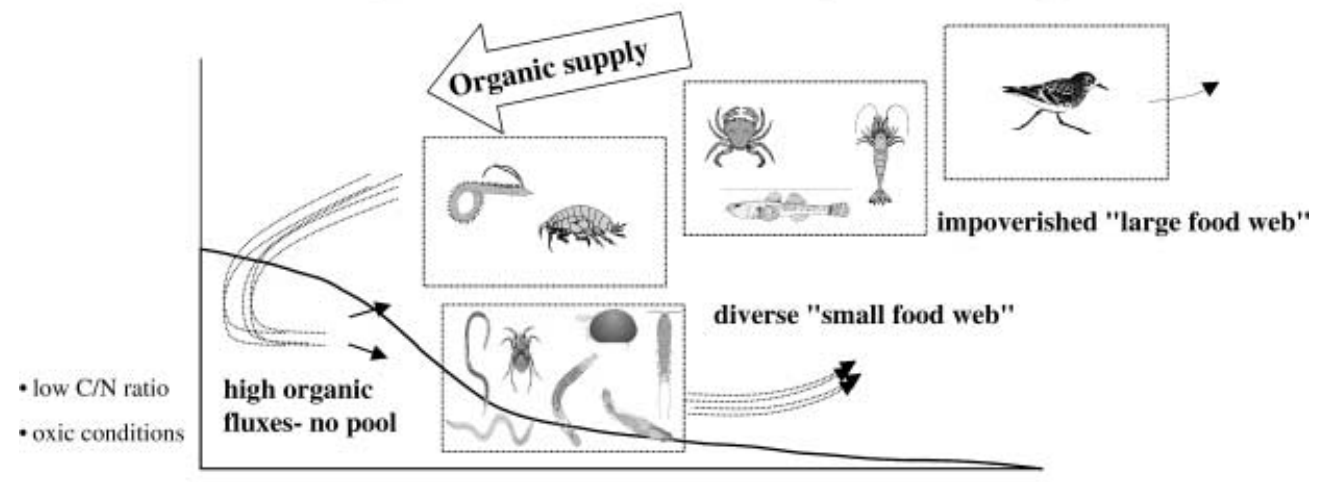

Accreting dissipative shore with low wave energy

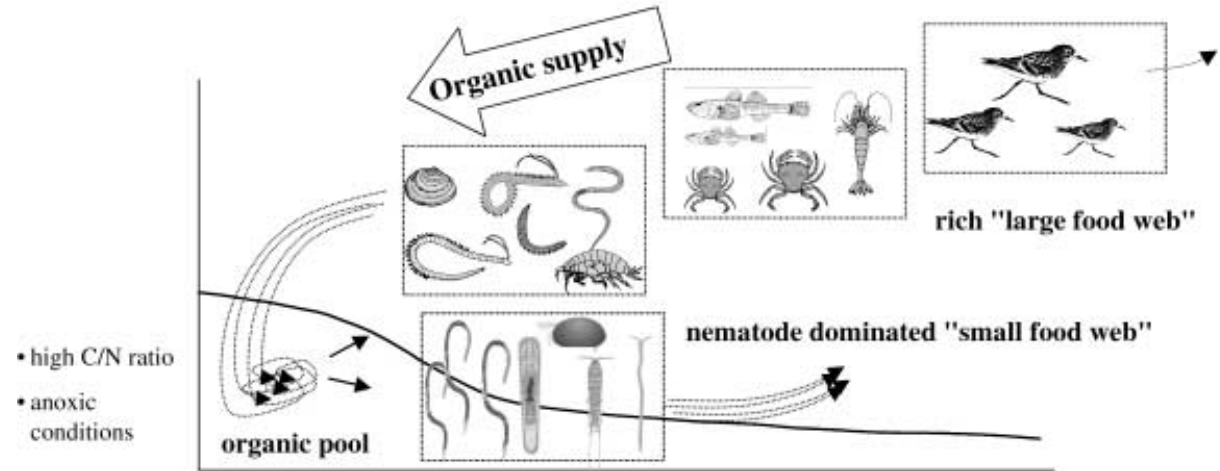


although absolute abundances of benthic prey species are not necessarily an adequate measure of their availability to predators (Ansell and Gibson 1990). Low abundances of macro- and epibenthos will in turn affect shorebirds foraging on invertebrates on sandy shores (Myers et al. 1982; Hockey et al. 1983), which is indicated by lower sanderling densities at Sylt than at Rømø. Sanderlings feeding on crustaceans, gastropods, bivalves and insects were the most numerous visitors on sandy shores in the study area, as has also been reported from shores in South Africa (Voous 1962; McLachlan et al. 1980; Myers et al. 1980).

"Small food web" (micro- and meiofauna)

The interstitial food chain consisting of bacteria, protists and meiofauna is partially separated from the macrobenthos-epibenthos-shorebird food web. The main energy flow through this system goes through bacteria utilizing dissolved and particulate organic matter received from the sea (Steele et al. 1970). Remineralized nutrients support microphytobenthos. Protozoans feed on bacteria and miroalgae, and also consume dissolved and particulate organic matter. Food sources for meiofauna are all these components and meiofauna itself (McIntyre et al. 1970; Munro et al. 1978; Alongi 1988; Brown and McLachlan 1990). Total meiofaunal abundance did not differ between Sylt and Rømø. This may indicate a similar food availability on both shores. However, at Sylt, agile meiofaunal organisms (i.e. most plathelminths, copepods, polychaetes) were most abundant, while the Røm $\varnothing$ shore was dominated by sluggish organisms (i.e. most nematodes). This may result from differences in the interstitial climate between the shores. The physical harshness of the eroding, intermediate shore may be counterbalanced by oxygen-rich conditions. On the accreting, dissipative shore a pronounced chemocline favours a dominance of nematodes (Menn 2002). As for the macrofauna, differences in availability of major food sources between the shores may also affect the meiofauna. At Sylt, the meiofauna need to be able to quickly use fresh organic matter progressing through the beach under high oxic conditions, resulting in the dominance of agile meiofaunal organisms. In contrast, at Røm $\varnothing$ the meiofauna may primarily exploit accumulated refractive organic material under low oxic or even anoxic conditions. Many nematodes are well adapted to this functional role (Heip et al. 1985; Giere 1993).

Meiofauna linked to almost all trophic compartments in the interstitial system attain a significant position within the "small food web". However, meiofauna do not represent a dead-end in the food chain, because there are several meiofauna-macrofauna interrelations. Meiofauna feed on juvenile macrofauna and itself serves to some extent as food for macrofauna (Reise 1979; Giere 1993). Thus, the meiofauna may have a central position in the entire benthic food web of exposed sandy shores. However, there is still a large gap in knowledge on the meio- fauna-food web and meiofauna-macrofauna interactions on sandy shores. This warrants further studies on this subject.

\section{Nutrient regeneration}

Sandy beaches have long been considered to be active in nutrient recycling by mineralizing organic matter received from the sea (Pearse et al. 1942). Several authors have proposed the great importance of sandy beaches in the inshore zone's self-purifying and regeneration mechanisms (Oliff et al. 1970; McLachlan 1979, 1982; Liebezeit and Velimirov 1984), while Hayes (1974) reported a rather insignificant nutrient efflux from beaches. At Sylt and Rømø, nutrient concentrations were higher in interstitial than in surf waters, indicating that both beaches are sources of nutrients originating from mineralization of organic matter. This is supported by the correspondence of an ammonium dominance in surf and interstitial waters at Rømø with anoxic sediment layers, and the nitrate dominance at Sylt with oxic conditions throughout. The results of this study provide no quantitative conclusions on efflux rates. Higher nutrient concentrations in interstitial waters on the dissipative shore than on the intermediate shore may result primarily from a lower permeability of the finer sediment at Rømø. High permeability due to coarse sediment at Sylt prevents any accumulation of nutrients. However, Huettel et al. (1998) proposed a high turnover rather than a low activity in non-accumulating sandy bottoms. Thus, the different nutrient concentrations in interstitial waters provide no evidence for a differential mineralization rate of the shores. Higher N-values (ammonium or nitrate, respectively) in surf waters on both shores than in the Sylt-Rømø Bight during the study period may indicate a high turnover on both shores (J. van Beusekom, personal communication).

\section{Conclusion}

The biotic system of the eroding, intermediate shore with high wave energy is mainly supplied by the actual organic loading from surf waters passing through the beach (Fig. 11). Meiobenthos is abundant and mainly composed of agile organisms, while macrobenthos, epibenthic predators, fish and shorebirds are all scarce. On the accreting, dissipative shore with low wave energy, part of the input is stored as organic carbon in the sediment, which then supports the biotic system. Meiobenthos is abundant, but sluggish organisms (many nematodes) dominate the assemblage. Macrobenthos, epibenthic predators and shorebirds are abundant. The intermediate shore may be characterized by an oxic nutrient regeneration, while on the dissipative shore anoxic mineralization also occurs.

As a corollary of global warming, the rise in sea level may accelerate, resulting in increasing hydrodynamic forces and enhanced erosion on the world's sandy shore- 
lines (Bruun and Asce 1962; Bird 1987; Führböter 1989; Lozán et al. 2001). This may enhance beach nourishment to combat erosion. Beach nourishment attempts to keep the shoreline at the same position, but it may also interrupt natural changes from reflective to dissipative shores (Short 1999). Thus, highly dynamic intermediate shores away from equilibrium state may be a result. On coldtemperate shorelines, such shores may be characterized by high fluxes of organic matter through the beach, but without storage of food sources in the sediment. They may primarily be used by a well developed "small food web" of agile organisms which are able to quickly exploit fresh organic material under high oxic conditions, while the "large food web" will decline.

Acknowledgements This research was supported by the Federal Ministry of Education and Research (BMBF) (no. 01 LK9514/0). I would like to thank the staff of the research vessel "Mya", Nils Kruse and Peter Elvert, for giving up many of their lunch breaks to enable the dredge sampling. The push-net sampling would have been impossible without many strong helpers and the know-how of Sönke Janssen. Dr. Justus van Beusekom, Dr. Ragnhild Asmus and Ludmilla Baumann helped with chlorophyll and nutrient analyses. Many thanks go to Dr. Achim Wehrmann and Torsten Janssen who carried out the $\mathrm{C} / \mathrm{N}$ analysis. Klaus Günther, Gregor Scheiffahrt and Lars Malte Rasmussen enabled inspiring discussions of the sanderling results. C. Hennig gave statistical advice. Last but not least, I am also grateful to Prof. Dr. Karsten Reise and Dr. Werner Armonies for their helpful comments and for critically reading the manuscript.

\section{References}

Ansell AD, Gibson RN (1990) Patterns of feeding and movement of juvenile flatfishes on an open sandy beach. In: Barnes M, Gibson RN (ed) Trophic relationships in the marine environment. Proceedings of the 24th EMBS, pp 191-207

Alongi DM (1988) Microbial-meiofaunal interrelationships in some tropical intertidal sediments. J Mar Res 46:349-365

Bartholdy J, Pejrup M (1994) Holocene evolution of the Danish Wadden Sea. Senckenb Marit 24:187-209

Bird ECF (1987) The modern prevalence of beach erosion. Mar Pollut Bull 18:151-157

Brown AC, McLachlan A (1990) Ecology of sandy shores. Elsevier Science, Amsterdam

Bruun P, Asce F (1962) Sea-level rise as a cause of shore erosion. ASCE Proceedings, J Waterway Habours Div 88:117-130

Cammen LM (1982) Effect of particle size on organic content and microbial abundance within four marine sediments. Mar Ecol Prog Ser 9:273-280

Christie ND (1976) A numerical analysis of the distribution of a shallow sublittoral sand macrofauna along a transect at Lamberts Bay, South Africa. Trans R Soc S Afr 42:149-172

Dette HH, Gärtner J (1987) Erfahrungen mit der Versuchsvorspülung vor Hörnum im Jahre 1983. Küste 45:209-258

Edwards RRC, Steele JH, Trevallion A (1970) The ecology of O-group plaice and common dabs in Loch Ewe. III. Prey-predator experiments with plaice. J Exp Mar Biol Ecol 4:156-173

Eleftheriou A, Holme NA (1984) Macrofauna techniques. In: Holme NA, McIntyre AD (ed) Methods for the study of marine benthos. Blackwell, Oxford, pp 141-216

Field JG (1970) The use of numerical methods to determine benthic distribution patterns from dredging in False Bay. Trans R Soc S Afr 39:183-200

Führböter A (1989) Changes of tidal waters at the German North Sea coast. Helgol Meeresunters 43:325-332
Giere O (1993) Meiobenthology. Springer, Berlin Heidelberg New York

Grasshoff K, Erhardt M, Kremling K (1983) Methods of seawater analysis. Verlag Chemie, Weinheim, Germany

Gray JS (1981) The ecology of marine sediments: an introduction to the structure and function of benthic communities. (Cambridge studies in modern biology 2) Cambridge University Press, Cambridge

Hamerlynck O, Cattrijsse A (1994) The food of Pomatoschitus minutus (Pisces, Gobiidae) in Belgian coastal waters, and a comparison with the food of its potential competitor P. lozanoi. J Fish Biol 44:753-771

Hayes WB (1974) Sand-beach energetics: importance of the isopod Tylos punctatus. Ecology 55:838-847

Heip C, Vincx M, Vranken G (1985) The ecology of marine nematodes. Oceanogr Mar Biol Annu Rev 23:399-489

Hermann J-P, Jansen S, Temming A (1998) Konsumption durch Fische und dekapode Krebse sowie deren Bedeutung für die trophischen Beziehungen in der Sylt-Römö Bucht. In: Gätje C, Reise K (ed) Ökosystem Wattenmeer. Springer, Berlin Heidelberg New York, pp 437-462

Hockey PAR, Siegfried WR, Crowe AA, Cooper J (1983) Ecological structure and energy requirements of the sandy beach avifauna of southern Africa. In: McLachlan A, Erasmus T (ed) Sandy beaches as ecosystems. W Junk, The Hague, pp 507521

Huettel M, Ziebies W, Forster S, Luther GW III (1998) Advective transport affecting metal and nutrient distributions and interfacial fluxes in permeable sediments. Geochim Cosmochim Acta 62:613-631

Lackschewitz D, Reise K (1998) Macrofauna on flood delta shoals in the Wadden Sea with an underground association between the lugworm Arenicola marina and the amphipod Urothoe poseidonis. Helgol Meeresunters 52:147-158

Lasiak TA (1981) Nursery grounds for juvenile teleosts: evidence from the surf zone of Kings Beach, Port Elizabeth. S Afr J Sci $77: 388-390$

Liebezeit G, Velimirov B (1984) Distribution of inorganic and organic nutrients in a sandy beach at Ischia, Bay of Naples. Oceanis 10:437-447

Lorenzen CJ (1967) Determination of chlorophyll and phaeo-pigments: spectrometric equations. Limnol Oceanogr 12:343-346

Lozán JL, Grassl H, Hupfer P (2001) Climate of the 21st century: changes and risks. Wissenschaftliche Auswertungen, Hamburg

McIntyre AD, Eleftheriou A (1968) The bottom fauna of a flatfish nursery ground. J Mar Biol Assoc UK 48:113-142

McIntyre AD, Munro ALS, Steele JH (1970) Energy flow in a sand ecosystem. In: Steele JH (ed) Marine food chains. Oliver and Boyd, Edinburgh, pp 19-31

McLachlan A (1979) Volumes of sea water filtered through Eastern Cape sandy beaches. S Afr J Sci 75:75-79

McLachlan A (1981) Exposed sandy beaches as semi-closed ecosystems. Mar Environ Res 4:59-63

McLachlan A (1982) A model for the estimation of water filtration and nutrient regeneration by exposed sandy beaches. Mar Environ Res 6:37-47

McLachlan A (1983) Sandy beach ecology - a review. In: McLachlan A, Erasmus T (ed) Sandy beaches and ecosystems. W Junk, The Hague, pp 321-380

McLachlan A, Wooldridge T, Schramm M, Kühn M (1980) Seasonal abundance, biomass and feeding of shore birds on sandy beaches in the Eastern Cape, South Africa. Ostrich 51:44-52

McLachlan A, Erasmus T, Dye AH, Wooldrige T, Horst G van der, Rossouw G, Lasiak TA, McGwynne L (1981a) Sand beach energetics: an ecosystem approach towards a high energy interface. Estuar Coast Shelf Sci 13:11-25

McLachlan A, Wooldridge T, Dye AH (1981b) The ecology of sandy beaches in southern Africa. S Afr J Zool 16:219-231

Mehner T (1992) Diet spectra of Pomatoschistus microps (Kroyer) and Pomatoschistus minutus (Pallas) (Teleostei, Gobiidae) during the first weeks after hatching. Zool Anz 229:13-20 
Meltofte H, Blew J, Frikke J, Rösner H-U, Smit CJ (1994) Numbers and distribution of waterbirds in the Wadden Sea: results and evaluation of 36 simultaneous counts in the DutchGerman-Danish Wadden Sea 1980-1991. Common Secretariat for Cooperation on the Protection of the Wadden Sea, Wilhelmshaven, Germany

Menn I (2002) Ecological comparison of two sandy shores with different morphodynamics in the North Sea. PhD thesis, University of Hamburg

Munro ALS, Wells JBJ, McIntyre AD (1978) Energy flow in the flora and meiofauna of sandy beaches. Proc RSE 76B: 297-315

Myers JP, Williams SL, Pitelka FA (1980) An experimental analysis of prey availability for sanderlings (Aves: Scolopacidae) feeding on sandy beach crustaceans. Can J Zool 58:1564-1574

Myers JP, Ruiz GR, Walters JR, Pitelka FA (1982) Do shorebirds depress their prey? Wader Study Group Bull 35:1-31

Noldt U, Wehrenberg C (1984) Quantitative extraction of living plathelminths from marine sands. Mar Ecol Prog Ser 20:193201

Oliff WD, Gardner BD, Turner WD, Sharp JB (1970) The chemistry of the interstitial water as a measure of conditions in a sandy beach. Water Res 4:179-188
Pearse AS, Humm HJ, Wharton GW (1942) Ecology of sandy beaches at Beaufort, North Carolina. Ecol Monogr 12:135-190

Pihl L (1985) Food selection and consumption of mobile epibenthic fauna in shallow marine areas. Mar Ecol Prog Ser 22:169-179

Reise K (1979) Moderate predation on meiofauna by the macrobenthos of the Wadden Sea. Helgol Meeresunters 32:453-465

Roberts G, Evans P (1993) Responses of foraging Sanderlings to human approaches. Behaviour 126:29-43

Sachs L (1984) Angewandte Statistik. Springer, Berlin Heidelberg New York

Short AD (1999) Handbook of beach and shoreface morphodynamcis. Wiley, Chichester

Short AD, Wright LD (1983) Physical variability of sandy beaches. In: McLachlan A, Erasmus T (ed) Sandy beaches as ecosystems. W Junk, The Hague, pp 133-144

Sokal RR, Rohlf FJ (1995) Biometry. Freeman, New York

Steele JH (1976) Comparative studies of beaches. Philos Trans R Soc Lond B 274:401-415

Steele JH, Munro ALS, Giese GS (1970) Environmental factors controlling the epipsammic flora on beach and sublittoral sands. J Mar Biol Assoc UK 50:907-918

Voous KH (1962) Die Vogelwelt Europas und ihre Verbreitung. Parey, Hamburg 